\title{
Balancing Gender and Power: How Disney's Hercules Fails to Go the Distance
}

\author{
Cassandra Primo \\ Departments of Business and Sociology, McDaniel College, Westminster, MD 21157, USA; crp002@mcdaniel.edu
}

Received: 26 September 2018; Accepted: 14 November 2018; Published: 16 November 2018

\begin{abstract}
Disney's Hercules (1997) includes multiple examples of gender tropes throughout the film that provide a hodgepodge of portrayals of traditional conceptions of masculinity and femininity. Hercules' phenomenal strength and idealized masculine body, coupled with his decision to relinquish power at the end of the film, may have resulted in a character lacking resonance because of a hybridization of stereotypically male and female traits. The film pivots from hypermasculinity to a noncohesive male identity that valorizes the traditionally-feminine trait of selflessness. This incongruous mixture of traits that comprise masculinity and femininity conflicts with stereotypical gender traits that characterize most Disney princes and princesses. As a result of the mixed messages pertaining to gender, Hercules does not appear to have spurred more progressive portrayals of masculinity in subsequent Disney movies, showing the complexity underlying gender stereotypes.
\end{abstract}

Keywords: gender stereotypes; sexuality; heroism; hypermasculinity; selflessness; Hercules; Zeus; Megara

\section{Introduction}

Disney's influence in children's entertainment has resulted in the scrutiny of gender stereotypes in its films (Do Rozario 2004; Dundes et al. 2018; England et al. 2011; Giroux and Pollock 2010). Disney's Hercules (1997), however, has been largely overlooked in academic literature exploring the evolution of gender portrayals by the media giant. The animated film is a modernization of the classic myth in which the eponymous hero is a physically intimidating protagonist that epitomizes manhood. Yet Disney's updated mythical hero had only moderate success at the box office. To date, Hercules has had a lifetime domestic gross total of just under $\$ 100$ million—only slightly exceeding its budget of $\$ 85$ million. While Hercules is comparable to Tarzan (1999)—another non-princess film released in a similar time period-Tarzan's gross proceeds have topped $\$ 170$ million. Both of these films, however, pale in comparison to the monetary success of the most recent Disney princess movie, Moana, with a lifetime gross of almost $\$ 250$ million after just two years (Box Office Mojo 2018a, 2018b, 2018c), one barometer of the films' success.

The fact that Hercules was "clearly a disappointment for Disney, whose aggressive marketing of the film included a traffic-choking Saturday night parade through Manhattan" (Fabrikant 1997, para 6) raises unanswered questions about the causes of its lackluster appeal, at least in comparative terms. Part of the answer to this question may relate to Disney's portrayal of a variety of gender tropes. In the reimagined age-old mythical character, Hercules, stereotypes were paired with an anomalous twist on conventional masculinity that may have been too avant-garde at the time of the film's release in 1997-and perhaps too progressive even more than 20 years later in 2018, judging from the subsequent and recent portrayals of Disney's male heroes.

In this analysis of Hercules, the title superhero exemplifies what seems to be a relatively early attempt by Disney to reconceive masculinity. However, coupled with manifold examples of gender 
stereotypes that pervade the film, the result is a hodgepodge of gender portrayals in which Disney fails to construct an appealing version of masculinity. As a result of these flaws, Disney neither challenges gender tropes nor presents a revised version of masculinity (see Macaluso 2018) that is likely to resonate with viewers, who must transcend a surfeit of cultural cues that valorize unambiguous hypermasculinity, such as the type embodied by Maui in Moana (2016).

\subsection{Plot Summary}

Baby Hercules is taken from Mount Olympus by Hades. As a result, he ends up living his life on Earth as a half-mortal until his teenage years. As he comes of age, Hercules begins to realize he is different and embarks on a journey of self-discovery to the Temple of Zeus. In the song "Go the Distance," Hercules avows his determination to overcome his insecurities and find his place, as well as a sense of belonging. Zeus reveals that he is Hercules' father and directs him to the satyr Philoctetes (Phil) to learn to become a "true hero" and return home.

On his mission to become a "true hero," Hercules travels to Thebes. On the way, Hercules meets Megara, a slave of Hades, with whom he falls in love. No matter how many monsters Hercules defeats, no act of strength and valor is enough to get him home to Mount Olympus. It is not until Hercules is willing to sacrifice his own life to save Megara that he is deemed a true hero, although he declines the power and position associated with such an honor, choosing instead the love of a woman, Megara.

\subsection{How Disney Modified the Original Story}

Disney's version strays significantly from the original myth, appropriating and altering major characters, such as Hera and Zeus, as well as Hercules. In the original myth, Hercules was born of adulterous relations between Zeus and Alcmene: a god and a mortal. Hercules was thus a living representation of betrayal that consumed Hera (the wife of Zeus), causing him to become the subject of her wrath; Hera attempted to kill him as a baby, but was unsuccessful. She brooded about this slight until she saw another opportunity to ruin Hercules. When he marries Megara, Hera compels Hercules into a temporary insanity, causing him to murder his wife, his own children, and several nephews.

Hercules also was scrubbed of violent traits in the Disney version, including the omission of killing his music teacher (Linus) and taking women at will. There is near erasure of these barbarous attributes in the Disney rendition, as the animated version built on a tabula rasa of sorts to create a portrayal designed to resonate with contemporary audiences in order to translate into marketable merchandise to build the Disney franchise.

Hera is also reconfigured from stepmother to mother of Hercules, and from frightening to gentle. Zeus is no longer a lustful adulterer, but instead is jocular and loyal to his wife (Burchfield 2013). In ancient myths, Hercules kills everyone he loves and falls into a suicidal depression, but in the Disney version, he is the champion of the tale, portrayed as a true hero that saves the girl (Burchfield 2013), diverging from the tragic ending that must be avoided in marketable Disney animated films (Pomeroy 2017).

\subsection{The Range of Gender Stereotypical Behavior Examined}

This paper suggests the film's weaknesses stem not only from its portrayal of Hercules, but also other depictions of gendered behavior. The film includes the representation of traditional femininity in Hera along with the Fates that are antithetical to idealized femininity, tropes that are common in Disney films (England et al. 2011). Phil and Pegasus reinforce gendered norms and further promote masculine superiority in their speech and actions. The tendency to emasculate male villains (Putnam 2013) is seen in Hades and his henchmen, Pain and Panic, which further encourages traditional masculinity, as well as hyper-heterosexuality.

This analysis explores how these characters overarchingly create mixed messages concerning the role of men and women in society. This paper relies on content analysis of the film, and findings from existing literature, both that includes coverage of Hercules and studies of gender in Disney films. 
In the realm of female gender norms, Disney has become less rigid; in Moana (2016), there is evidence that a more androgynous portrayal of the title character is apparent to child viewers who do not, however, generally consider Moana to be a princess (Hine et al. 2018). Because of the $\$ 3$ billion in retail sales in 2011 of the Disney Princess brand (Goudreau 2012), there are clearly financial obstacles to more progressive gender roles that deviate from stereotypical princess traits. While Hercules is not considered a Disney princess film due to the characterization and implications of the would-be prince and princess, the reasons for the film's exclusion from this category illustrate how certain gender norms are deeply entrenched and are only recently starting to depart from longstanding tropes, at least in the case of princesses (Hine et al. 2018), that arguably have more latitude in terms of acceptable behavior that is gendered (Coyle et al. 2016).

\section{Zeus and Hera}

\subsection{Display of Traditional Gender Roles}

Gender stereotypes manifest from the beginning of the film, with a scene that depicts a baby Hercules with his doting parents, Zeus and Hera. Hera's portrayal in the film does not go beyond this limited maternal role. In the 21st century, women are no longer expected to solely act as their child's caretaker during the child's formative years (Henderson et al. 2016). Yet in the 1980s and into the 1990s, mothers experienced social pressure to stay at home and, when possible, to avoid or minimize daycare or preschool programs, ostensibly for children's safety and well-being (Walker 2010). Disney's modernization of the story reflects this zeitgeist, changing Hera from a terrifying adversary to a completely docile character who is an appendage of Zeus and whose only purpose is to serve as Hercules' mother. Her role is reinforced in the mere nine lines she speaks, all of which relate to her maternity, with the outlier being a comment on the loveliness of flowers.

Hera is seen in only three scenes throughout the film; she serves her one-dimensional, stereotypical function as a mother during the celebration of Hercules' birth, again when he is kidnapped, and last when Hercules is being welcomed home (Zipes 1999). When Hera and Zeus discover that Hercules has disappeared, she can be seen hiding behind Zeus before dramatically falling to the ground and breaking down in tears. In direct contrast to what can be labeled as Hera's "womanly reaction" (Sharrock 2011), Zeus becomes exceedingly angry. The sky mirrors his rage, manifested in flashes of lightning and roars of thunder-storm power that is typically the domain of men (Dundes et al. 2018) and reflected in the thunderbolt gold medallion Hercules wears even as a baby. Thus, Hera is portrayed as helpless and as nothing more than a grieving mother, whereas Zeus can be seen demanding and instigating action in response to crises. These characters in Disney's version of Hercules exemplify both classic stereotypes and modern constructs of men and women: physical versus emotional, strong versus incapable, and tough versus beautiful (Smelik 2015). The implications of the portrayals of Zeus and Hera include those traditionally embedded in Disney films (Towbin et al. 2004); Zeus encourages physical response to emotion, strength, and heroism, while Hera personifies the anachronistic idealized woman: beautiful, domesticated, and helpless.

\subsection{Supplanting Hera}

The very first setting of the movie is Mount Olympus in the midst of a celebration of the birth of Hercules, where Hera can be seen cradling her baby and showing stereotypical motherly affections: cooing, kissing, adoring, and protective actions. When Hera asks Zeus what gift to bestow on Hercules, in keeping with a baby shower (Afflerback et al. 2014), Zeus ponders the question and then, without consulting his wife, uses his power to create and give life to Pegasus, who emerges from his hand, an example of male parthenogenesis in which procreativity is achieved manually (Dundes et al. 2018). Thus, Zeus effectively usurps even the biological female ability to give birth-further promoting his superiority. This paints Hera in a powerless light, where she is not only incapable, but also essentially superfluous in providing for Hercules. 


\section{The Fates}

\subsection{Women in Power}

In Hercules, a trio of cadaverous and ghoulish crones, the Fates, are purportedly omniscient, eternal beings, who relish having the life of every single mortal at their mercy. Their severe physical deformities coexist with their power over life and death, suggesting that powerful women pay a price for their dominance over mortal men. The Fates are also blind, gaining sight through a singular eye that they pass around to see the present unfold, a handicap limiting their power. Beyond this unbecoming disfigurement, the Fates are not depicted as neutral beings, but in fact serve Hades in his attempt to overthrow Zeus. As a result, they arguably are subordinate to the primary power dynamic, which is male against male. Furthermore, these powerful, immortal beings are adversarial to the hero's quest, essentially making them villains (Coville 2010).

It is no mistake that Hera, the maternal figure in the film, embodies the definition of beautiful, while the Fates have an unmatched level of power, but are physically repulsive. They echo the modern trend in which women who choose a demanding career in which they struggle to accommodate a husband and co-parenting risk accusations of selfishness and thoughtlessness (Griffin et al. 2017).

\subsection{Other Powerful Disney Women}

Powerful women in animated Disney movies are typically portrayed by evil, old, disfigured, or altogether villainous characters (Coville 2010), e.g., Ursula in The Little Mermaid, the queen in Snow White, the stepmother in Cinderella, Maleficent in Sleeping Beauty, or Te Kā as the lava monster in Moana (Streiff and Dundes 2017a). While Elsa in Frozen is an exception as a conventionally attractive character, her power (that she struggles to control when beset by emotion) seems to preclude male romantic interest (Streiff and Dundes 2017b). These powerful Disney women are often juxtaposed against purity and attractiveness, and their own morality and appearance distinctly oppose the ultra-feminine title princess. This pattern-in accordance with the Fates and in contradistinction to Hera-suggest a reality where women cannot have it all; they are either beautiful and powerless or powerful and ugly.

\section{Phil and Pegasus}

\subsection{Comments on Female Intelligence}

Phil (Hercules' personal trainer and coach) implies an association between femininity and incompetence when he attempts to promote his own masculine abilities by derogating women with his quip, "Who do you think taught Jason to sail? Cleopatra?" [26:12-21]. The subtext of this statement is that Cleopatra, with her legendary beauty, did not also have nautical skills, which presumably would have humiliated Jason (leader of the Argonauts). This statement is encompassed by Phil's boasts of his superior abilities in training infamous male heroes; the only mention of a woman is a disparaging comment projecting the impossibility of female excellence in a profession traditionally portrayed as contingent on male determination.

\subsection{Feminization of Pegasus}

There are also gender implications in the ostensibly comedic feminization of Pegasus. In one instance, when Zeus says that Pegasus has "the brain of a bird," [22:23-26] Hercules' equine companion transforms dramatically from the strong, "magnificent horse" Zeus describes just seconds before. Similarly, after Hercules completes his training, one of his first aspirations is to go "rescue some damsels" [31:21-23]. In this scene, Pegasus attempts to resemble a damsel, which changes his physical appearance and mannerisms. In both of these instances, there is some incorporation of the following: Pegasus' eyelashes extend, his wings and feathers appear flashier and more bouffant, and he adopts a stance or struts in poses associated with feminine beauty ideals (Baker-Sperry and Grauerholz 2003). These scenes portray male feminization as comedic (Patterson and Spencer 2017) and support the 
implications of Phil's commentary. The personification of a "bird brain" with female sensibility and the belief that women need rescue from a valorous, male hero are both overarching themes concerning women in Disney films (Towbin et al. 2004). Both Phil and Pegasus insinuate that women do not have and cannot match the intelligence of their male counterparts, which arguably indoctrinates children to assume female inferiority.

\section{Pain, Panic, and Hades}

\subsection{Male Dominance and Sexuality}

To compensate for his feminine actions, Pegasus affirms his masculinity at the end, when one of Hades' henchmen, Pain, says to Pegasus: "My intentions were pure! I really was attracted to you" and is then pummeled by Pegasus. Pain's avowal of attraction to Pegasus refers to when he and Panic transform themselves into a highly sexualized and feminine horse that causes Pegasus to extend his tongue, as if panting in lust [1:05:50-1:06:10]. The mare has a heart on its back flank in a position similar to the so-called "tramp-stamp" (found on the small of a woman's back), which is seen as indicating openness to sexual relations (Leader 2016). Having assumed the form of a seductive female horse, the pair lead Pegasus to a candlelit room with a bed and proceed to discard the previously worn lace saddle (presumably pseudo lingerie). Soon after, they unwittingly reveal their actual identity. Pegasus then beats them in an attempt to reassert his masculinity after inadvertently showing sexual interest in characters who displayed transgendered qualities, a pattern previously noted (see Putnam 2013). This homophobic act of Pegasus clobbering Pain arguably serves to bolster Pegasus' masculinity at the expense of Pain (whose sexuality is unclear) [1:17:56-1:18:01]. Pegasus' distress caused by his accidental attraction to men makes him like a female- the ones who are supposed to be attracted to males. This is insulting because in being feminized, the implication is that he loses status, a problem exacerbated by the stigma associated with gay males.

Pain's sexuality is suggested during his character's introduction, when he is sexually impaled twice when tumbling down stairs [7:04-17]. The first instance is of Pain landing on a three-pronged decoration. The second occurs at the end of the tumble, where Panic's phallic head-forks penetrate Pain long enough for them to be seen by Hades in a vulnerable, homoerotic state. Shortly thereafter, Pain and Panic grovel before Hades in an unequivocally humiliating manner; this repentance alongside the transformation of both men into worms (a term of contempt) could evince that deviation from heterosexual norms, and thus traditional maleness, is undesirable and necessitates forgiveness or even remediation.

\subsection{The Association of Male Villainy with Queerness}

Characterized as Hades' henchmen, Pain and Panic are designed to be unattractive, detestable creatures who relish the opportunity to harm and deceive. This is evident first when the pair smiles over baby Hercules during their attempt to murder him, and again when they fail, but decide to delude Hades. Pain and Panic embrace these classically villainous traits, and evoke an association between evil and the deviation from masculinity and heterosexuality (Patterson and Spencer 2017; Putnam 2013).

Hades also conveys uncertain sexuality, especially in comparison to his adversary, Zeus. In the original myth, Hades ruled the underworld alongside his queen, Phosphorene. In the Disney revival, though, Zeus retains his queen, while Hades rules the underworld alone. This lack of a partner-and no apparent interest in females-coupled with a head that is literally "flaming," could connote that a "flaming gay male" (which Hades personifies) is most challenging to heteronormativity (Clarkson 2008). In fact, effeminate Disney villains are a consistent pattern (Towbin et al. 2004; Patterson and Spencer 2017; Putnam 2013).

The absolute villainization of Hades is historically incorrect per mythology, which raises the question of why he was characterized this way in the Disney film. Ancient adversaries, such as 
Zeus and Hades, classified each other as rivals, not as demonic and inhuman (Burchfield 2013); yet Hades is depicted as just that: a hellish ghoul with razor sharp teeth and unsightly stature-very different from his classic normative appearance. This illustration arguably works to further mark his subordination to his hypermasculine, hyper-heterosexual brother, Zeus, who dominates Hades in every battle. The comedic vilification of Hades reflects a societal marginalization of the "flaming gay man" and invites audiences to laugh at the character. Pain and Panic's fear of Hades may also mirror debate among gay males about how to reconcile the "heteronormative sex and gender regime" with gay identity (Clarkson 2008, p. 379).

Despite a successfully cultivated connection to the gay community (Griffin 2000), Disney continues to demonize characters who are overtly queer. Pain and Panic impersonate a highly sexualized female to achieve their goal of distracting Pegasus, supporting the claim that male villains are often subjected to feminization to prove their inferiority to the hypermasculine hero (Li-Vollmer and LaPointe 2003). Their actions also argue that female usefulness comes from their power of seduction, which is further perpetuated by Hades via his interactions with Megara.

\section{Megara}

\subsection{Oversexualization}

Megara, a princess character from mythology (the daughter of King Creon of Thebes), exemplifies gender stereotypes by the emphasis on her looks and sexuality. Megara is Hades' slave because she sold her soul to him, and as such, Hades expects her to help to win his war using the sway of her hips; within the context of the film, Megara chose to "sell herself", and it is worth noting that this is played out in terms of her sexuality. Primarily, Hades identifies her as having "the right curves" to throw at Hercules and wants her to bring him down by "handling him as a man." When Meg finally complies, won over by Hades' promises of freedom, the portrayal of Meg with Hercules depicts her speaking in a sultry voice while seductively cavorting and touching Hercules provocatively [56:40-58:58] (Rabison 2016). As a femme fatale, blatantly exploiting her sexuality, her actions are patently treacherous, designed to invite contempt (Valenti 2009). Not only is she reduced to what society views as a disgraceful woman, she is also unsuccessful in her ploy, as Hercules is revealed to be a superior, respectful man, turning down her repeated sexual advances.

Her role as a seductress is further established by Hades through his use of derogatory "pet" names that show dominance (rather than sexual interest). Notably, after declaring she will no longer honor his demands, she is physically bound and held hostage to ensure Hercules' compliance. After the execution of the final step in Hades' plan, despite Megara's disobedience, Hades refers to her as "sugar, sweetheart, babe," terms of endearment that in this context reinforce both Megara's subservient role and her sexuality.

\subsection{Megara and the Muses}

Megara's role as a femme fatale is made more prominent by her lead singing role in "I Won't Say I'm In Love," with the Muses as accompanists. In this song, the baring of her inner struggles not only signals her importance to the plot, but also makes use of songs as a tool to enhance audience connection with the characters (McGill 2018). By exposing the audience to Megara's emotional turmoil when she develops feelings for someone she is also betraying (Hercules), the song reinvents her character and promotes a powerful connection between her and the audience (a phenomenon explored by McGill (2018)). The song solidifies Megara's tribulations as a woman in love-facilitating the audience's ability to feel a rapport with her as they recognize the complications surrounding love and see the centrality of sex and love in Megara's life.

In this musical scene, the Muses fulfill a prominent supporting role, not only musically, but also as characters who encourage Megara to let herself fall in love with Hercules. However, these Black women who belt out gospel music only serve a subsidiary role as sexualized women who 
voice appreciation for Hercules' manly attributes; as women of color, they are not taken seriously as romantic prospects for Hercules, a facet of the film that has been condemned (see Foote 2010). Instead, they serve as the chorus, both in the plot and musically, working to promote Megara's-but not their own-interests. This portrayal reinforces long-term patterns of women of color in helping roles (Dundes and Streiff 2016; Gregory 2010), part of a matrix of oppression that demands not just improvement, but wholesale redress (Harris 2018).

What explains Megara's melodramatic mood when singing about her repressed affection for Hercules? She believes him to be entirely unlike her last love, who betrayed her, and she even openly admits that she thinks Hercules is perfect. So why does she fight falling in love with this ideal man? Megara's seductive prowess is as a tool to seduce Hercules and satisfy the man who supervises the use of her sexual allure (Hades), and thus she feels emotionally constrained (in line with common perceptions of expectations for paid sex workers). Megara is perfectly aware of her position and the impracticality of falling for a man she has been assigned to seduce. She refers to love as "rotten judgment" and urges herself to "get a grip" over her emotions during the song. The Muses, however, as a useful instrument for Megara, propel her towards an epiphany: She realizes she does indeed love Hercules. Ultimately, this scene enhances her complexity as she grapples with her deceit, which is now a form of betrayal.

\subsection{Selflessness}

Megara not only acts in the role of deceitful seductress, but also embodies stereotypically female characteristics, such as sacrifice, selflessness, affection, and nurturing (England et al. 2011). When offered her freedom in return for information on how to defeat Hercules, Megara decides she would rather remain a slave than be responsible for the downfall of someone she loves. She later demonstrates the same kind of altruistic sacrifice when she pushes Hercules out of the way of a falling pillar, ultimately ending up underneath the structure herself-an intentionally lethal move. Megara performs this act without glorification; despite inconsistencies with traditional Disney princesses, that is, Megara's typology as "street-wise" paired with "sexual confidence" (see Davis 2006, p. 210), she nevertheless demonstrates that selflessness for women is expected, not extraordinary.

\subsection{Not A Disney Princess}

Megara is perhaps the most complex female protagonist Disney had designed to date at the release of Hercules. She is not inherently pure like the classic princesses-e.g., Snow White, Aurora, Cinderella-as she is the first to express being in a relationship prior to meeting her "prince." For this previous partner, she was willing to give her freedom for his life, yet he ran off with another woman in the end. This theme deviates from the stories of prior princesses and has yet to be explored again within the princess franchise. Her sexual innocence is lost due to this history with another man, and her character is then further compromised through extensive sexualization by Hades.

Megara, however, is also not a traditional Disney villainess, as she is attractive, young, and ultimately desired by the title hero. She works for the main villain, but against her will as a "slave." Unlike the Fates, who are also associated with Hades, Megara does not derive pleasure from the downfall of Hercules, but rather is seen encouraging his success throughout the film. Furthermore, her climax comes in the moment she is willing to sacrifice everything for the one she loves, which aligns with the classic princess theme of female sacrifice.

Nevertheless, the complexity of Megara's role as a beautiful villain that ultimately ends up with the hero sharply contradicts what children are socialized to believe about how princess characters behave. Thus, while Megara is a character representative of a woman in the real world, she is not an idealized princess, nor the epitome of evil. She performs both insidious and altruistic acts, but arguably all in the name of love. This behavior upends the usual gender norms portrayed in a Disney fairy tale story and is perhaps responsible for keeping her from joining the esteemed ranks of a Disney princess. 


\section{Hercules}

\subsection{As a Traditional Male Hero}

Like Megara, Hercules models traits that defy gender norms associated with male heroes: intimidating physical dominance and strength, courage and bravery, a journey of growth, lack of sexual inhibition, and emotional apathy (Campbell 1949; England et al. 2011; Davis 2013; Gillam and Wooden 2008; Matyas 2010; Towbin et al. 2004). Hercules clearly has uncommon brawn, proven by his ability to slay monsters and titans in Thebes and Mount Olympus. Prior to his journey of growth (in which he discovers his purpose, endures trials in Thebes, and refuses to return to Mt. Olympus (Campbell 1949)), Hercules appears physically inferior, judging from his musculature; however, his strength is unmatched by any mortal man. After training with Phil, Hercules' developed muscles and toned figure align with his physical ability. The Muses in Hercules even emphasize his hypermasculine physique in their song "Zero to Hero," in which Hercules is described as a "hunk" and a "gladiator." For example, the Muses sing, "Folks lined up; Just to watch him flex; And his perfect package; In a pair of pretty pecs."

Hercules also executes grand displays of courage and bravery as he engages and slays each one of Hades' monsters. He performs so well against and without fear of these adversaries that the city of Thebes immortalizes him in statues, art, and everyday items (cups, toys, etc.). Hercules displays ample confidence in this regard, actively acknowledging his status and accomplishments. The Muses reinforce this behavior in the same way they rank his physical traits, singing, "Sweet and undefeated; And an awesome 10 for $10 . "$

On his journey of growth, Hercules meets Megara, and falls for her based solely on her physical beauty. Both his first and second trials as a hero revolve around his newfound love interest-the first is an attempt to save her from Nessus (the river guardian) and the second trial is at her behest (to save Pain and Panic, disguised as children). Despite falling in love with her, however, Hercules does not succumb to sexual temptation. Instead he encourages decency and abstinence: He replaces her dress strap after it falls from her shoulder and discourages her advances by his refusals to take advantage of her sexual availability [57:43-58:58]. This reveals how Hercules differs from the traditional male hero, specifically his sexual restraint that is driven by either fear from inexperience or perhaps an emotional connection that replaces apathy, cited as a conventionally heroic trait (above).

\subsection{As a Novel Male Hero}

Hercules' juxtaposition against Zeus throughout the film includes a culminating scene in which Hercules prefers sacrificing his strength and glory for love, eschewing the traditional masculinity exuded by his father. The underlying plot of the film revolves around the power struggle between Zeus and Hades, neither of whom are particularly relatable to viewers. Thus, the climatic heroic act is the saving of Megara from the underworld. In this instance, Hercules faces with determination the ultimate challenge of his ability for the sake of one life, and he is victorious (as Zeus deems this act to be of true heroism, elevating him from demigod to god in power). What makes Hercules different from male protagonists, such as Eric of The Little Mermaid, or Prince Phillip of Sleeping Beauty, is that the heroic act of saving the woman results in the revocation of the hero's status, authority, and power.

These major sacrifices support conflicting implications of what determines a male hero. Hercules' journey of growth includes the development of physical brawn, which bolsters his strength and overall power-supporting the general theme that masculine heroes should strive to be physically strong. When granted the ultimate strength of a god, though (literally shown theatrically through the glowing of his skin), Hercules willingly sacrifices his newfound power (and therefore his glow) to stay with Megara, potentially suggestive of the male preoccupation about shininess that is associated with sexual readiness (see Dundes et al. 2018). Thus, Hercules' climatic act of heroism involves his sacrifice of the masculine reward of power in lieu of love. 
In this way, the ending of Hercules differs from other Disney films. In Pocahontas (1995), it is the title character who gives up adventure and love for duty and to meet the needs of others (Dundes 2001). In The Little Mermaid (1989), it is Ariel who gives up family and community and even her own voice for a time, for love (Hynes 2010). In Hercules, though, the male hero gives up greatness in a way that upstages the female protagonist and her willingness to sacrifice.

\subsection{Not a Disney Prince}

In his choice to remain with Megara, Hercules forgoes his long-sought, rightful place at Zeus' right hand and the accompanying power of the position. This is arguably the most pertinent point, suggesting Hercules is not a Disney prince. No prince prior was required to sacrifice their position to be with the princess (and Aladdin is even elevated in status and authority through his union with Jasmine (Aladdin, 1992)). Because it is impossible for Megara to become his princess should he choose to remain with his royal parents, he surrenders his princely title to stay with the woman of choice.

This is a novel dynamic in a Disney film for its time: A man engages in a sort of selflessness that creates a happier outcome for both himself and the woman he loves. Hercules does not want to be superior in status to Meg, but rather merely wishes to be an equal. This is radical compared to male characters in the Disney animated films prior to Hercules, as male protagonists have tended to be the heroic love interest, exuding masculinity, rather than characters that engage in self-sacrifice (England et al. 2011). The ending of Hercules arguably promotes gender equality in that a male was willing to sacrifice stature for the sake of woman, in fact, for a woman without power or position.

The implication of Hercules' decision is that love is more important than any power or authority, which is typically a sentiment reserved for the female protagonist in Disney films (Towbin et al. 2004). His selflessness occurs in the absence of compensatory acts that support traditional masculinity and contrast with his phallic thunderbolt-wielding father Zeus, whose power far exceeds that of Hercules. In theater, the hero is ultimately supposed to save the day, win the love of a woman, and retain their power and status; however, Hercules departs from the traditional male gender role in that he not only prioritizes love, but finds happiness in giving up power. This raises the question of whether Hercules may fail to resonate with viewers socialized to embrace characters that exemplify traditional masculinity.

In addition to the more blatant departure from gender norms, Hercules also agonizes about "Going the Distance" (in his only song that presents his plight to viewers), with lyrics that show his anxieties as he is coming of age. The song could be obliquely referencing sexual anxiety (given the argot about "going all the way"). He does not embrace his physical power, which makes him different, but is more concerned about how his superhuman strength means that he does not fit in. In contrast, Elsa (in Frozen, 2016), who like Hercules is powerful and does not fit in, nevertheless embraces this difference, making her a compelling and popular character. In lowering his status to become a mere mortal at the end, Disney has inadvertently feminized him, making him less appealing to viewers who expect to see males who aspire to gain stature at the same time as they pursue a worthy romance. While such a portrayal may be more in line with erasing gender roles, Hercules still possesses other elements of hypermasculinity-and ultimately has limited ability to serve as a role model if he is not relatable.

\section{Impact on Subsequent Films}

\subsection{Movement Away from Princes and Princesses}

Less than a year after the release of Hercules, Mulan premiered in theaters, and this debut was followed a year later by Tarzan; both films were likely already in production and were not influenced by the success or failure of Hercules. At the turn of the 21st century, however, there is a distinct shift in the content of Disney films-there is no princess/prince dynamic again until 2009 with Princess and the Frog. Disney/Pixar largely focused on stories of parental and platonic love, altering their focus from 
male/female love stories ending in matrimony; Monsters Inc., Finding Nemo, and The Incredibles are some of the greatest successes of this decade. The larger point is the noticeable absence of a Disney princess title film. Even the live-action remake films did not begin producing princess renditions until 2014 with Maleficent. Hercules may have had an impact on this decision since the success Disney experiences as a company is based both on blockbuster films and their merchandise (Tracy 1999). Prior to the release of Hercules, the most lucrative Disney franchise was that of the Disney princess, and it continues to be most popular among young girls (Coyne et al. 2016). Hercules is perhaps too great a departure from the gender patterns of the princess genre.

\subsection{Tangled (2010)}

The resurgence of princess movies arguably began with Tangled (2010), which achieved greater success than Princess and the Frog (2009). Reactions to the lack of conformity to gender stereotypes in Hercules were possibly considered in the characterization of the protagonists, Rapunzel and Eugene, in Tangled. Rapunzel is absolute in her purity, naivety, and beauty. Her purity is due to a total lack of romantic experience, unlike Megara who engaged in a romantic entanglement prior to Hercules. Rapunzel is also impossibly naïve, having no concept of the "outside world" or the reality of the world she lives in (a theme recapitulated in princess Anna of Frozen); this is distinctly opposite of Megara, who arguably has too much knowledge of the world. Perhaps most obvious, though, are Rapunzel's looks, specifically her eyes, which have returned to that of the classic princess. In complete contradistinction to Megara, Rapunzel's eyes are wide with awe and wonder, not narrow in suspicion and deceit. The frying-pan-wielding princess may seem strong and independent, but just like Ariel, her adventurous soul is overcome by love and it is her prince that climatically saves the day with a heroic deed (Elnahla 2015).

Eugene, however, is not a prince in the same way Megara is not a princess. His self-interested thieving makes him a borderline villain at the start of the film. Regarding male gender roles, however, and in comparison to Hercules, Eugene's character has qualities of the traditional male hero: strength, courage, a journey of growth, and physical masculinity (Campbell 1949; Davis 2013; England et al. 2011; Gillam and Wooden 2008; Towbin et al. 2004). In the "Snuggly Duckling" pub scene, Eugene's hypermasculinity is emphasized through the foil of the physically intimidating 'thugs' who all aspire to do domestic work (like bake cupcakes and knit) versus Eugene's proclamation that he does not share their tendencies toward the so-called "touchy-feely."

Eugene's character is even taken a step further than prior Disney princes, designed with facial hair to bolster his masculinity. Perhaps most importantly though, Eugene never has to sacrifice power, authority, or status, differentiating him from Hercules. In fact, through his heroic deeds, he gains these things in his relationship with Rapunzel. The greatest sacrifice Eugene makes is that of his life for Rapunzel's - which has been deemed the act of a true hero when performed by men, and therefore only again serves to fortify Eugene's masculinity and his ability to win the heart of the virginal Rapunzel. The extent to which Rapunzel and Eugene reflect traditional gender roles is arguably partially a result of the failings of Hercules in navigating appealing gender roles.

\subsection{Moana (2016)}

While recent research (Hine et al. 2018) shows Disney moving towards androgenic portrayals of female leads in films like Moana, there has yet to be such latitude permitted to male heroes. Disney's character Maui, for example, in Moana (2016), who like Hercules is a demigod, gains status through hypermasculinity, which is exaggerated to the point of his violating the goddess Te Fiti with his beloved phallic fishhook (Streiff and Dundes 2017a). The presumed likeability of Maui's character further illustrates that audiences may be more likely to embrace traditional male heroes. While Herculean is an adjective denoting strength, Hercules' willingness to sacrifice power for love of a woman could be seen as too empowering for women and thus too threatening to male hegemony-and the failure of 
his character to resonate with viewers arguably influenced the hypermasculinity of the subsequent demigod Maui.

\section{Conclusions}

Disney is historically one of the most prominent creators of animated children's movies and has achieved an almost unmatched level of influence via expansive media coverage of its productions (Giroux and Pollock 2011). However, its films generally reflect, but do not necessarily change societal values of an era-leading to the socialization of children to imitate the gender-specific roles performed by their favorite princes and princesses (Garabedian 2014). In Hercules, these roles are confusing and do not align with prior learned behaviors. Lackluster engagement with the film, both while in theaters and with post-release merchandise, may therefore have slowed Disney's promotion of a new prince and princess paradigm.

Disney has the power to help teach young boys and girls to both respect themselves and others as they are. It has the ability to show girls they can be both loveable and powerful, and to show boys they can be both powerful and kind. Critics that bemoan the influence that Disney wields often fail to acknowledge the role of audience predilections. This perhaps includes audiences' limited embrace of characters like Megara, who is morally ambiguous, and Hercules, who does not capitalize on masculine traits like physical strength (and relies on Zeus for the dramatic dispatch of adversaries). While Hercules does not display the characteristics normally expected in order to establish the hero's dominance (when he relinquishes power and authority), his behaviors also exist within a context replete with other gender stereotypical behavior, which show that in expanding conceptions of male heroism, Disney may have created a character that was not sufficiently relatable. In addition, Hercules' preference for the more mundane rewards of a relationship in lieu of the exhibition of hypermasculinity may have been too avant-garde in 1997. Another possibility may be that the complexities of gender traits and their implications could have been too confusing for young viewers to grasp. Time will tell if the film or others with similar themes will appeal to new generations of viewers as normative gender roles evolve.

Funding: This research received no external funding.

Conflicts of Interest: The author declares no conflict of interest.

\section{References}

Afflerback, Sara, Amanda Koontz Anthony, Shannon K. Carter, and Liz Grauerholz. 2014. Consumption Rituals in the Transition to Motherhood. Gender Issues 31: 1-20. [CrossRef]

Baker-Sperry, Lori, and Liz Grauerholz. 2003. The Pervasiveness and Persistence of the Feminine Beauty Ideal in Children's Fairy Tales. Gender and Society 17: 711-26. [CrossRef]

Box Office Mojo. 2018a. Hercules (1997). Available online: https://www.boxofficemojo.com/movies/?page= main\&id=hercules.htm (accessed on 24 September 2018).

Box Office Mojo. 2018b. Moana (2016). Available online: https:/ / www.boxofficemojo.com/movies/?page=main\& $\mathrm{id}=$ disney1116.htm (accessed on 24 September 2018).

Box Office Mojo. 2018c. Tarzan (1999). Available online: https://www.boxofficemojo.com/movies/?id=tarzan.htm (accessed on 24 September 2018).

Burchfield, Amy. 2013. Going the Distance: Themes of the Hero in Disney's Hercules. Brigham Young University Scholars Archive. All Theses and Dissertations. 4291. Available online: https://scholarsarchive.byu.edu/cgi/ viewcontent.cgi? article $=5290 \&$ context $=$ etd (accessed on 25 July 2018).

Campbell, Joseph. 1949. The Hero with a Thousand Faces. Novato: New World Library, vol. 13.

Clarkson, Jay. 2008. The Limitations of the Discourse of Norms. Journal of Communication Inquiry 32: 368-82. [CrossRef]

Coville, Stephanie J. 2010. Representations of Women in Films Aimed at Young Girls: An Extended Literature Review. Faculty of Education Graduate Projects. Available online: https:/ / qspace.library.queensu.ca/handle/ 1974/5578 (accessed on 2 September 2018). 
Coyle, Emily F., Megan Fulcher, and Darinka Trübutschek. 2016. Sissies, Mama's Boys, and Tomboys: Is Children's Gender Nonconformity More Acceptable When Nonconforming Traits Are Positive? Archives of Sexual Behavior 45: 1827-38. [CrossRef] [PubMed]

Coyne, Sarah M., Jennifer Ruh Linder, Eric E. Rasmussen, David A. Nelson, and Victoria Birkbeck. 2016. Pretty as a Princess: Longitudinal Effects of Engagement with Disney Princesses on Gender Stereotypes, Body Esteem, and Prosocial Behavior in Children. Child Development 87: 1909-25. [CrossRef] [PubMed]

Davis, Amy. 2006. Good Girls and Wicked Witches: Women in Disney's Feature Animation. London: John Libbey Publishing.

Davis, Amy. 2013. Handsome Heroes and Vile Villains: Masculinity in Disney's Features Films. Bloomington: Indiana University Press.

Do Rozario, Rebecca-Anne C. 2004. The princess and the magic kingdom: Beyond nostalgia, the function of the Disney princess. Women's Studies in Communication 27: 34-59. [CrossRef]

Dundes, Lauren. 2001. Disney's modern heroine Pocahontas: Revealing age-old gender stereotypes and role discontinuity under a façade of liberation. The Social Science Journal 38: 353-65. [CrossRef]

Dundes, Lauren, and Madeline Streiff. 2016. Reel Royal Diversity? The Glass Ceiling in Disney's Mulan and Princess and the Frog. Societies 6: 35. [CrossRef]

Dundes, Lauren, Madeline Streiff, and Zachary Streiff. 2018. Storm Power, an Icy Tower and Elsa's Bower: The Winds of Change in Disney's Frozen. Social Sciences 7: 86. [CrossRef]

Elnahla, Nada Ramadan. 2015. Aging with Disney and the Gendering of Evil. Journal of Literature and Art Studies 5: 114-27.

England, Dawn Elizabeth, Lara Descartes, and Melissa A. Collier-Meek. 2011. Gender Role Portrayal and the Disney Princesses. Sex Roles 64: 555-67. [CrossRef]

Fabrikant, Geraldine. 1997. Hercules Is Too Weak to Lift Disney Stock. New York Times. Available online: https: / www.nytimes.com/1997/07/10/business/hercules-is-too-weak-to-lift-disney-stock.html (accessed on 14 October 2018).

Foote, Lena. 2010. "I Want to be a Princess Too": Exploring the Blackout of Disney's Princess and the Frog and Its Effects on African American Girls. Film Matters 2: 13-22. [CrossRef]

Garabedian, Juliana. 2014. Animating Gender Roles: How Disney is Redefining the Modern Princess. James Madison Undergraduate Research Journal 2: 22-25.

Gillam, Ken, and Shannon R. Wooden. 2008. Post-Princess Models of Gender: The New Man in Disney/Pixar. Journal of Popular Film and Television 36: 2-8. [CrossRef]

Giroux, Henry A., and Grace Pollock. 2010. The Mouse That Roared: Disney and the End of Innocence. Lanham: Rowman \& Littlefield.

Giroux, Henry A., and Grace Pollock. 2011. Is Disney Good for Your Kids? How Corporate Media Shape Youth Identity in the Digital Age. In Kinderculture, 3rd ed. Edited by Shirley R. Steinberg. New York: Taylor \& Francis, pp. 73-92.

Goudreau, Jenna. 2012. Disney Princess Tops List of the 20 Best-Selling Entertainment Products. Forbes. Available online: https:/ / www.forbes.com/sites/jennagoudreau/2012/09/17/disneyprincess-tops-list-of-the-20best-selling-entertainment-products (accessed on 24 October 2018).

Gregory, S.M. 2010. Disney's second line: New Orleans, racial masquerade, and the reproduction of whiteness in The Princess and the Frog. Journal of African American Studies 14: 432-49. [CrossRef]

Griffin, Sean. 2000. Tinker Belles and Evil Queens: The Walt Disney Company from the Inside Out. New York City: New York University Press.

Griffin, Martyn, Nancy Harding, and Mark Learmonth. 2017. Whistle While You Work? Disney Animation, Organizational Readiness and Gendered Subjugation. Organization Studies 38: 869-94. [CrossRef]

Harris, Heather E. 2018. Queen Phiona and Princess Shuri-Alternative Africana "Royalty" in Disney's Royal Realm: An Intersectional Analysis. Social Sciences 7: 206. [CrossRef]

Henderson, Angie, Sandra Harmon, and Harmony Newman. 2016. The Price Mothers Pay, Even When They Are Not Buying It: Mental Health Consequences of Idealized Motherhood. Sex Roles 74: 512-26. [CrossRef]

Hercules [Motion Picture]. 1997. Directed by Ron Clements, and John Musker. Burbank: Walt Disney Pictures.

Hine, Benjamin, Katarina Ivanovic, and Dawn England. 2018. From the Sleeping Princess to the World-Saving Daughter of the Chief: Examining Young Children's Perceptions of 'Old' versus 'New' Disney Princess Characters. Social Sciences 7: 161. [CrossRef] 
Hynes, Ashlee. 2010. Raising Princesses? Gender socialisation in early childhood and the Disney Princess franchise. Critical Social Thinking: Policy and Practice 2: 205-18.

Leader, Karen. 2016. “On the book of my body": Women, Power, and "Tattoo Culture". Feminist Formations 28: 174-95. [CrossRef]

Li-Vollmer, Meredith, and Mark E. LaPointe. 2003. Gender Transgression and Villainy in Animated Film. Popular Communication 1: 89-109. [CrossRef]

Macaluso, Michael. 2018. Postfeminist Masculinity: The New Disney Norm? Social Sciences 7: 221. [CrossRef]

Matyas, Vanessa. 2010. Tale as Old as Time: A Textual Analysis of Race and Gender in Disney Princess Films. Graduate Major Research Papers and Multimedia Projects. Available online: https:/ / macsphere.mcmaster.ca/ handle/11375/14406 (accessed on 2 September 2018).

McGill, Craig M. 2018. 'This Burning Desire is Turning Me to Sin': The intrapersonal sexual struggles of two Disney singing villains. Queer Studies in Media E Popular Culture 3: 27-49.

Patterson, G., and Leland G. Spencer. 2017. What's so funny about a snowman in a tiara? Exploring gender identity and gender nonconformity in children's animated films. Queer Studies in Media \& Popular Culture 2: 73-93.

Pomeroy, Arthur J. 2017. A Companion to Ancient Greece and Rome on Screen. Malden: John Wiley \& Sons, Inc., pp. 214-15.

Putnam, Amanda. 2013. Mean ladies: Transgendered villains in Disney films. In Diversity in Disney Films: Critical Essays on Race, Ethnicity, Gender, Sexuality and Disability. Edited by Johnson Cheu. Jefferson: McFarland \& Company Inc., pp. 147-62.

Rabison, Rebecca. 2016. Deviance in Disney: Of Crime and the Magic Kingdom. In Debating Disney: Pedagogical Perspectives on Commercial Cinema. Edited by Douglas Brode and Shea T. Brode. Lanham: Rowman \& Littlefield, pp. 199-210.

Sharrock, Alison. 2011. Womanly wailing? The mother of Euryalus and gendered reading. Eugesta 1: 55-77.

Smelik, Anneke. 2015. A close shave: The taboo on female body hair. Critical Studies in Fashion \& Beauty 6: 233-51.

Streiff, Madeline, and Lauren Dundes. 2017a. From shapeshifter to lava monster: Gender stereotypes in Disney's Moana. Social Sciences 6: 91. [CrossRef]

Streiff, Madeline, and Lauren Dundes. 2017b. Frozen in Time: How Disney Gender-Stereotypes Its Most Powerful Princess. Social Sciences 6: 38. [CrossRef]

Tangled [Motion Picture]. 2010. Directed by Byron Howard, and Nathan Greno. Burbank: Walt Disney Pictures.

Towbin, Mia Adessa, Shelley A. Haddock, Toni Schindler Zimmerman, Lori K. Lund, and Litsa Renee Tanner. 2004. Images of Gender, Race, Age, and Sexual Orientation in Disney Feature-Length Animated Films. Journal of Feminist Family Therapy 15: 19-44. [CrossRef]

Tracy, James F. 1999. Whistle While You Work: The Disney Company and the Global Division of Labor. Journal of Communication Inquiry 23: 374-89. [CrossRef]

Valenti, Jessica. 2009. The Purity Myth: How America's Obsession with Virginity is Hurting Young Women. Berkeley: Seal Press.

Walker, Bela August. 2010. Deciphering Risk: Sex Offender Statutes and Moral Panic in a Risk Society. University of Baltimore Law Review 40: 184-213.

Zipes, Jack. 1999. Breaking the Disney Spell. In The Classic Fairy Tales: A Norton Critical Edition, 1st ed. Edited by Maria Tatar. New York: W. W. Norton \& Company, pp. 333-52.

(c) 2018 by the author. Licensee MDPI, Basel, Switzerland. This article is an open access article distributed under the terms and conditions of the Creative Commons Attribution (CC BY) license (http://creativecommons.org/licenses/by/4.0/). 